\title{
Students' entrepreneurial behavior: international and gender differences
}

\author{
Tugrul Daim ${ }^{1 *}$, Marina Dabic ${ }^{2,3}$ and Elvan Bayraktaroglu ${ }^{4}$
}

\author{
* Correspondence: \\ tugrul.u.daim@pdx.edu \\ ${ }^{1}$ Technology Management Doctoral \\ Program, Portland State University, \\ 1900 SW 4th, Portland, OR 97201, \\ USA \\ Full list of author information is \\ available at the end of the article
}

\begin{abstract}
Due to a high level of uncertainty, entrepreneurship is generally considered a risky endeavor. This paper explores the factors impacting entrepreneurial behavior in order to identify new educational opportunities for its development. The paper explores perceived feasibility and desirability for students in 10 countries. The entrepreneurship role is gender tested against desirability and feasibility. The requirements for developing this skill set are also studied. A survey instrument was developed, and data was collected from 4281 students. The results indicate that gender impacts entrepreneurship intention and the way it impacts is influenced by which country the students are from.
\end{abstract}

Keywords: Entrepreneurship, International differences, Gender differences, Behavior, Higher education

\section{Background}

The noteworthy contribution of entrepreneurial activities to economies (Keilbach and Sanders, 2008) in terms of growth, innovation, job creation, and poverty reduction (Lunati et al., 2010) makes entrepreneurship a popular research topic. The OECD-Eurostat Entrepreneurship Indicators Programme defines entrepreneurs as "those persons (business owners) who seek to generate value, through the creation or expansion of economic activity, by identifying and exploiting new products, processes or markets" (Lunati et al., 2010). Entrepreneurs differ from the rest of the society ostensibly by their propensity to take risk, tolerance for ambiguity, and motivation for self-employment. Hines (1973) sees entrepreneurship as a role model and bases his reasoning on a conclusion that entrepreneurs strive for greater realization and accomplishment in comparison to the role that is fostered by non-entrepreneurial activity. According to Summers (2000), the main aspect of entrepreneurship is "the critical combination of the individual, his or her past experience, background and the decision to start an enterprise." Increasing interest in entrepreneurship also raised the curiosity for the drivers such as intentions, traits, behavioral patterns, and external and contextual factors leading individuals to entrepreneurship phenomenon.

The study of entrepreneurial motivations has a long history. According to Summers (2000), primal publications were mainly focused on traits, such as self-

(c) 2016 Daim et al. Open Access This article is distributed under the terms of the Creative Commons Attribution 4.0 International License (http://creativecommons.org/licenses/by/4.0/), which permits unrestricted use, distribution, and reproduction in any medium, provided you give appropriate credit to the original author(s) and the source, provide a link to the Creative Commons license, and indicate if changes were made. 
confidence, risk tolerance, and tolerance for ambiguity. On the way to more recent intention-based process models (Shapero, 1982), later studies for entrepreneurial motivation were based on several other perspectives, such as demographic characteristics (gender, age, education, etc.), social factors (family, community, etc.), and external influences (politics, capital availability, etc.) (Summers, 2000). More recent process models for entrepreneurial motivation are "focusing on attitudes and beliefs and how they can predict intentions and behaviors" (Segal et al., 2005). These models are mainly based on human cognitive processes to distinguish possible desirable outcomes and to make decisions on the feasibility of acting to obtain those outcomes (Segal et al., 2005).

As mentioned above, country-specific factors were examined in relation with entrepreneurship in the literature. For instance, in their study where they compared $15 \mathrm{EU}$ member countries and the USA in terms of latent and actual entrepreneurship, Grilo and Irigoyen (2005) indicate that the level of entrepreneurship shows distinct differences across countries. They pointed out that countryspecific effects are indicative for both entrepreneurial motivation and activity levels. According to Freytag and Thurik (2007), country-specific effects are significant for entrepreneurship preferences but in contrast to that result they do not seem to be able to explain entrepreneurial activity. In their 2006-dated paper, Lee et al. 2006 tried to determine the disparities among the examined countries regarding the aspects essential to improve the entrepreneurship education. Also, Carayannis et al. (2003) indicate that there are differences between American and French entrepreneurship students in terms of attitudes and perceptions towards entrepreneurship.

Female and male entrepreneurs usually operate in different sectors and pursue different ways to develop their business. Therefore, increased number of female entrepreneurs means increased entrepreneurship variety in economy (Verheul et al. 2004). Notwithstanding the importance of their contribution in terms of entrepreneurship variety, the number of female entrepreneurs is lower than that of male entrepreneurs in almost every country in terms of Total Entrepreneurial Activity, except Ghana, Costa Rica, and Australia (Kelley et al. 2010). This result is also supported with the entrepreneurship literature. For instance, according to Grilo and Irigoyen (2005), for the evaluated $15 \mathrm{EU}$ member countries and the USA, the probability of preference for self-employment is notably higher for men compared to women. Menzies and Tatroff's (2006) work on gender differences on preferences on entrepreneurship education also states that less women are interested in entrepreneurship education compared to men. Zhang et al. (2009) indicate that there is a difference between genders regarding the genetic basis of entrepreneurship.

The purpose of this paper is to examine whether gender and country of residence differences have a significant impact on entrepreneurial intentions of university students as measured by perceived feasibility and perceived desirability. So our research question is the following:

What are the gender and country differences' impacts on entrepreneurial intentions of university students? 
This paper focuses on university-level students as a result of the conviction that younger people are more willing to be self-employed (Blanchflower et al., 2001; Grilo and Irigoyen, 2005). According to GEM's 2010 global report, in the case of age distribution of entrepreneurs, the 24-35 age group has the highest population for almost every geographic region. Since university students generally fall into the 18-24 age group, examining their entrepreneurial intentions as potential future entrepreneurs might reveal some implications, because according to Ajzen (1991) intention is anterior to act.

The next section examines the entrepreneurial behavior literature with a focus on university students and corresponding national setting and gender differences. Then hypotheses are introduced. This is followed by the description of research design and the methodology conducted. The paper concludes with the discussion of the results and the recommendations for future research.

\section{Literature review and hypotheses}

Entrepreneurial motivations have been frequently examined in the literature. Chell and Allman (2003) explored intentions of more technology-oriented entrepreneurs, while Krueger et al. (2000) analyzed differing entrepreneurial intentions. Grilo and Thurik (2005) explored barriers in 15 European countries and the USA and tried to explain differences in those countries in terms of latent and actual entrepreneurship. Studies of entrepreneurship attitudes among students have been viewed as an emerging topic due to an increase in the research performed on that subject by authors such as Luthje and Franke (2003), Wang and Wong (2004), Huffman and Quigley (2002), and Johnson et al. (2006). These studies test entrepreneurial attitudes against differing behavioral characteristics to elaborate on a model that would be used as a tool for prediction of future behavior.

Among the authors who modeled and examined the behavioral relationship between university students and the corresponding national setting are Turker and Selcuk (2008), Wu and Wu (2008), Wang and Wong (2004), Menzies and Tatroff (2006), Verheul et al. (2004), Kourilsky and Walstad (1998), Zhang et al. (2009), Elenurm et al. (2007), Petridou et al. (2009), Shariff and Saud (2009), Liñán (2008), Carayannis et al (2003), and Veciana et al. (2005).

In Turker and Selcuk's (2008) study, similar to Wu and Wu's (2008) and Lee and Wong's (2004), educational setting is seen as a significant factor spurring entrepreneurship. While $\mathrm{Wu}$ and $\mathrm{Wu}$ (2008) credit educational significance for assisting in realization of potential behavior, Wang and Wong (2004) see this realization emanating from appropriate curriculum structure. Liñán (2008) identified the role of perceived skill as an important factor impacting entrepreneurial intention. Shariff and Saud (2009) explored students' attitudes towards entrepreneurship in Malaysia and found that self-esteem and personal control differences were influential. Carayannis et al (2003) compared French and US students on their attitudes and perceptions of entrepreneurship and identified regional differences. Barriers against entrepreneurial behavior have long been studied.

Menzies and Tatroff (2006) explored attitudes of students in Canada as well, but they also looked at gender differences. They identified no differences in attitudes towards taking risks, but fewer women tended to think that entrepreneurship fit 
their personality. They also reported on studies citing how education helped increase the number of female entrepreneurs. Verheul et al. (2004) explored similar factors in a US university and found similar results. Kourilsky and Walstad (1998) also identified similar differences in a US-wide study and proposed entrepreneurship-focused curricula. Zhang et al. (2009) explored genetic differences between genders and their impact on entrepreneurship. Petridou et al. (2009) identified that there were differences in attitudes towards entrepreneurship education and perceptions about required skills between the two genders. Eddleston and Powell (2008) examined how gender identity explains what male and female business owners look for from their careers and found that gender identity, represented by the dimensions of masculinity and femininity, serves as a cognitive mechanism that contributes to differences in business owners' career satisfaction preferences. Verheul et al. (2004) explored female entrepreneurship in 29 countries and found that similar factors impacted both genders. Grilo and Thurik (2005) also identified gender differences in a study conducted in the general population. Gerry and Marques (2008) identified similar differences in Portugal. Both were exploring entrepreneurship as a choice. However, Fischer et al. (1993) argued against these differences and found that there was no difference in the success rate at the end.

Based on the above discussion, our hypotheses below were developed:

H1-Gender in different countries makes a difference in students' attitudes towards entrepreneurship as measured by desirability and feasibility one country at a time. H2-Country of residence makes a difference in students' attitudes towards entrepreneurship as measured by desirability and feasibility.

\section{Methods}

Shapero's model (1982), augmented by Krueger and Brazeal (1994), underlines the basis of our research. We draw our conclusions from the reasoning that intentions are predictions for future behavior. Shapero divided all the characteristics that could initiate intentions into two groups which consist of perceived desirability and perceived feasibility (Summers, 2000). Perceived desirability is defined as a subjective norm regarding the perceived social support and personal interest to perform the entrepreneurial behavior. Perceived feasibility examines the perceived ease or difficulty of performing the entrepreneurial behavior and the perceived selfcompetence regarding to entrepreneurship.

Accordingly, we suggest in this paper a model (Fig. 1) that provides insight into the entrepreneurial intensions of students in terms of genders and country of residence differences.

A survey instrument was developed, and data was collected from 4281 students from Croatia (1918), Slovenia (306), Austria (541), Poland (332), France (442), Lithuania (415), Israel (295), India (16), and other countries (16) of which 2712 were female and 1563 were male students. This paper is a part of a survey that collected data on the perceived feasibility and desirability of students in more than 10 countries.

In this theoretical framework, to examine the concept of perceived desirability, students were asked to measure the extent to which they agreed or disagreed with 


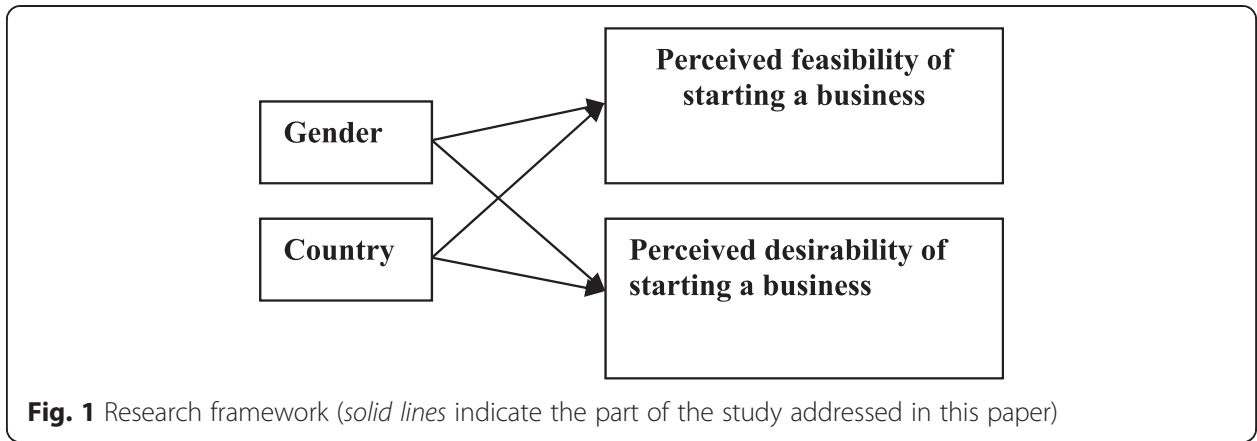

the following statements regarding their personal level of desirability for starting their own businesses after the completion of their education: (1) "I would love to do it"; (2) "My immediate family members would encourage me to do it"; (3) "I would be tense"; and (4) "I would be enthusiastic." Students answered by choosing a number on a Likert scale from 1 to 6 , with 1 representing "not at all" and 6 "extremely." In order to investigate students' perceptions on the feasibility of starting a new business, the following questions were included in the survey: (1) "It would be very hard to do"; (2) "I am certain that I would be successful"; (3) "I would be overworked"; (4) "I know enough to start a business"; and (5) "I trust myself." In each question, students were able to choose their answers on a Likert scale of 1 to 6 , this time with 1 being "very much agree" and 6 being "very much disagree."

As a difference from the previous two studies of Dabić et al. (2012a, 2012b), this study used the same data with the addition of survey results from India and some other countries used to evaluate the impact of gender and country of residence differences on entrepreneurial intentions of university students as measured by perceived feasibility and perceived desirability. In this study, countries were analyzed separately in terms of entrepreneurial intention differences based on country of residence and gender. As a result, significant differences were found among countries and genders in terms of desirability and feasibility towards entrepreneurship. Results indicated that Poland, Slovenia, and India seem to have little difference between male and female genders whereas responses from Croatia, Austria, France, and Israel revealed quite strong difference among male and female students. In the other study of Dabić et al. (2012a), perceived desirability, perceived feasibility, and educational needs in terms of entrepreneurial programs/activities/projects at an academic institution were analyzed from the gender difference perspective only. Results of the analysis showed that there were significant differences between genders' perception for educational needs to construct academic entrepreneurship education and networking and tutoring channels for students. In Dabić et al. (2012b), countries in the sample were clustered into four groups. The first cluster was created from the questionnaires collected in Israel with the reasoning that Israel is the country with a high entrepreneurial culture, a high level of development, but a low level of political integration. The second cluster consisted of the countries which are in the EU for a longer period of time, namely France and Austria. These two countries have a high level of 
economic and political development and integration. The third cluster was comprised of Lithuania, Poland, and Slovenia and forms a cluster with characteristics of countries that recently joined the EU and are of a medium level of political and economic development and integration. The fourth cluster was formed by only one country, namely Croatia, as it is a country which is awaiting its accession to the EU and which made a number of political and economic reforms but which has a low level of political integration and a lower level of development than the previous three clusters.

\section{Results and discussion}

\section{Starting a new business: desirability}

As can be seen in Table 1, the average response to the statement "I would love to do it" $(\bar{x}=4.12)$ shows a positive attitude regarding the desirability of entrepreneurial activities for students. The highest score among the statements on desirability is with family support $(\bar{x}=4.50)$, meaning that students felt they would generally have the benefit of high family encouragement. Also, it is important to note that the same statements have the highest standard deviation $(\sigma=1.894)$, indicating relatively high difference among students. The lowest average score in the group is agreement with the statement of being tense as an entrepreneur $(\bar{x}=4.04)$. However, relatively low agreement on this factor can be regarded as a positive indicator towards entrepreneurial attitude, since it suggests students are not highly certain such activities will lead to negative emotions, like tension or stress. Furthermore, enthusiasm scores $(\bar{x}=4.33)$ indicate positive mood in connection with starting a new business. This measurement has the second lowest standard deviation in the desirability group $(\sigma=1.487)$. Country-specific means show differences and will be analyzed in the next section.

\section{Starting a new business: feasibility}

It is interesting to observe the results of student perceptions on feasibility in connection with starting a new business. As can be seen in Table 2, the lowest average

Table 1 Perceived desirability-descriptive statistics

\begin{tabular}{lcccc}
\hline Country & Desirability 1 (D1) & Desirability 2 (D2) & Desirability 3 (D3) & Desirability 4 (D4) \\
\hline Croatia & 4.66 & 5.07 & 4.21 & 4.70 \\
Austria & 3.69 & 4.33 & 4.47 & 4.36 \\
France & 4.29 & 4.44 & 4.16 & 4.62 \\
Israel & 4.02 & 4.49 & 4.40 & 4.68 \\
Lithuania & 1.83 & 1.97 & 2.37 & 1.78 \\
Poland & 4.19 & 4.12 & 3.51 & 4.31 \\
Slovenia & 4.23 & 4.97 & 4.41 & 4.49 \\
India & 4.44 & 3.81 & 3.38 & 4.94 \\
Rest of the World & 4.00 & 4.69 & 4.50 & 4.75 \\
All & 4.12 & 4.50 & 4.04 & 4.33 \\
\hline
\end{tabular}

Desirability: (D1) I would love to do it; (D2) My immediate family members would encourage me to do it; (D3) I would be tense; and (D4) I would be enthusiastic. Agreement: (1) not at all; (2) slightly; (3) somewhat; (4) moderately; (5) very much; and (6) extremely 
Table 2 Perceived feasibility-descriptive statistics

\begin{tabular}{llllll}
\hline Country & Feasibility 1 (F1) & Feasibility 2 (F2) & Feasibility 3 (F3) & Feasibility 4 (F4) & Feasibility 5 (F5) \\
\hline Croatia & 2.03 & 2.82 & 1.86 & 3.49 & 2.42 \\
Austria & 2.13 & 3.43 & 2.08 & 3.60 & 2.65 \\
France & 2.03 & 3.30 & 2.32 & 4.35 & 3.26 \\
Israel & 2.14 & 2.60 & 2.39 & 3.59 & 2.42 \\
Lithuania & 3.01 & 3.19 & 2.98 & 3.99 & 2.93 \\
Poland & 2.56 & 3.35 & 2.50 & 3.65 & 3.01 \\
Slovenia & 2.28 & 2.67 & 2.50 & 3.45 & 2.28 \\
India & 1.88 & 2.38 & 2.00 & 3.50 & 2.00 \\
Rest of the World & 2.13 & 3.50 & 2.00 & 3.88 & 2.56 \\
All & 2.20 & 3.00 & 2.17 & 3.66 & 2.62 \\
\hline
\end{tabular}

Feasibility: (F1) It would be very hard to do; (F2) I am certain that I would be successful; (F3) I would be overworked; (F4) I know enough to start a business; and (F5) I trust myself. Agreement: (1) very much agree; (2) strongly agree; (3) mildly agree; (4) mildly disagree; (5) strongly disagree; and (6) very much disagree

score $(\bar{x}=2.17)$ and standard deviation $(\sigma=1.112)$ occur for the question describing how overworked the entrepreneur expects to be. This could lead to the conclusion that students have the perception of being overworked if they start their own businesses. As for the certainty of success, the average score $(\bar{x}=3.00)$ indicates that students were right in the middle between most affirmative and most negative, meaning, on average, they were neither certain nor uncertain of success. The average score for the question regarding knowing enough to start a business $(\bar{x}=3.66)$ is slightly negative, meaning students are a little unsure whether they know everything they need to start a business and thus may benefit from some additional education in this area. For the self-confidence question, results show students have a positive perception $(\bar{x}=2.62)$. Nevertheless, they agree with the contention that starting a new business is quite hard $(\bar{x}=2.20)$. Country-specific means show differences and will be analyzed in the next section.

Based on Table 3, the average of responses for perceived desirability questions 1 through 4 can be seen gender- and countrywise. According to these results, the average of total responses for desirability question 1 regarding attitudes towards entrepreneurial initiatives and that for desirability question 4 regarding enthusiasm about entrepreneurial initiatives seem higher for male students. Furthermore, the average of total scores for desirability questions 2 and 3 regarding family support and work-related stress, respectively, may imply that although female students feel slightly more supported by their families they are inclined to feel more tense about starting a new business. Another interesting outcome is that female students from Poland and India seem to show equal or greater inclination to entrepreneurial initiatives compared to male students from those countries. Also, country-specific means show differences and will be analyzed in the next section.

Based on Table 4, the average of responses for perceived feasibility questions 1 through 5 can be seen gender- and countrywise. According to these descriptive statistics, for feasibility questions 1 and 3, regarding the difficulties associated with entrepreneurial activities and being overworked, respectively, female students' total average scores are smaller than male students'; for questions 2 , 4, and 5, regarding 
Table 3 Perceived desirability means by gender and country-descriptive statistics

\begin{tabular}{|c|c|c|c|c|c|c|}
\hline Country & Gender & & Desirability 1 & Desirability 2 & Desirability 3 & Desirability 4 \\
\hline \multirow[t]{2}{*}{ Croatia } & Female & Mean & 4.56 & 5.14 & 4.29 & 4.60 \\
\hline & Male & Mean & 4.82 & 4.95 & 4.10 & 4.84 \\
\hline \multirow[t]{2}{*}{ Austria } & Female & Mean & 3.54 & 4.34 & 4.46 & 4.22 \\
\hline & Male & Mean & 4.14 & 4.32 & 4.49 & 4.78 \\
\hline \multirow[t]{2}{*}{ France } & Female & Mean & 4.08 & 4.44 & 4.29 & 4.47 \\
\hline & Male & Mean & 4.62 & 4.44 & 3.95 & 4.84 \\
\hline \multirow[t]{2}{*}{ Israel } & Female & Mean & 3.60 & 4.23 & 4.57 & 4.55 \\
\hline & Male & Mean & 4.51 & 4.79 & 4.21 & 4.82 \\
\hline \multirow[t]{2}{*}{ Lithuania } & Female & Mean & 1.82 & 1.96 & 2.37 & 1.77 \\
\hline & Male & Mean & 1.84 & 1.99 & 2.36 & 1.79 \\
\hline \multirow[t]{2}{*}{ Poland } & Female & Mean & 4.19 & 4.27 & 3.57 & 4.31 \\
\hline & Male & Mean & 4.19 & 3.80 & 3.37 & 4.31 \\
\hline \multirow[t]{2}{*}{ Slovenia } & Female & Mean & 4.12 & 5.00 & 4.41 & 4.44 \\
\hline & Male & Mean & 4.46 & 4.91 & 4.40 & 4.61 \\
\hline \multirow[t]{2}{*}{ India } & Female & Mean & 5.60 & 4.80 & 3.00 & 6.00 \\
\hline & Male & Mean & 3.91 & 3.36 & 3.55 & 4.45 \\
\hline \multirow[t]{2}{*}{ Rest of the world } & Female & Mean & 4.25 & 4.75 & 4.38 & 4.88 \\
\hline & Male & Mean & 3.75 & 4.63 & 4.63 & 4.63 \\
\hline \multirow[t]{4}{*}{ Total } & Female & Mean & 3.99 & 4.52 & 4.10 & 4.23 \\
\hline & Female & Std. dev. & 1.703 & 1.703 & 1.517 & 1.486 \\
\hline & Male & Mean & 4.36 & 4.46 & 3.94 & 4.50 \\
\hline & Male & Std. dev. & 1.616 & 2.187 & 1.384 & 1.475 \\
\hline
\end{tabular}

certainty of success, certainty of having the required knowledge for entrepreneurial activities, and self-confidence, respectively, male students score smaller. These results may imply that female students are more concerned about the difficulties and workload associated with entrepreneurship and they have lower self-confidence and motivation under the assumption of starting a new business. Also, country-specific means show differences and will be analyzed in the next section.

\section{Gender and country differences}

Differences were analyzed in multiple perspectives as seen in Table 5. ANOVA was used in each case, and the detailed results are provided in the following tables.

At the $1 \%$ level of significance, ANOVA indicates relevant differences among different countries for all the previously mentioned questions regarding perceived feasibility and perceived desirability as can be observed in Table 6 .

\section{Countrywise differences with respect to desirability}

Based on the significance values for desirability questions 1 through 4 , there is a statistically significant difference between countries for the following: desirability question $1\left(D 1 P_{v}=0.000\right)$ regarding attitudes towards entrepreneurial initiatives, desirability question $2\left(D 2 P_{v}=0.000\right)$ regarding family support, desirability 
Table 4 Perceived feasibility means by gender and country-descriptive statistics

\begin{tabular}{|c|c|c|c|c|c|c|c|}
\hline Country & Gender & & Feasibility 1 & Feasibility 2 & Feasibility 3 & Feasibility 4 & Feasibility 5 \\
\hline \multirow[t]{2}{*}{ Croatia } & Female & Mean & 1.95 & 2.89 & 1.81 & 3.57 & 2.53 \\
\hline & Male & Mean & 2.14 & 2.72 & 1.95 & 3.38 & 2.27 \\
\hline \multirow[t]{2}{*}{ Austria } & Female & Mean & 2.10 & 3.53 & 2.04 & 3.76 & 2.78 \\
\hline & Male & Mean & 2.23 & 3.15 & 2.20 & 3.12 & 2.26 \\
\hline \multirow[t]{2}{*}{ France } & Female & Mean & 1.98 & 3.35 & 2.30 & 4.53 & 3.50 \\
\hline & Male & Mean & 2.11 & 3.22 & 2.35 & 4.07 & 2.89 \\
\hline \multirow[t]{2}{*}{ Israel } & Female & Mean & 2.17 & 2.78 & 2.50 & 3.69 & 2.61 \\
\hline & Male & Mean & 2.12 & 2.39 & 2.27 & 3.47 & 2.20 \\
\hline \multirow[t]{2}{*}{ Lithuania } & Female & Mean & 2.98 & 3.35 & 2.95 & 4.13 & 3.10 \\
\hline & Male & Mean & 3.06 & 2.89 & 3.04 & 3.75 & 2.62 \\
\hline \multirow[t]{2}{*}{ Poland } & Female & Mean & 2.50 & 3.31 & 2.45 & 3.67 & 3.12 \\
\hline & Male & Mean & 2.69 & 3.43 & 2.60 & 3.62 & 2.77 \\
\hline \multirow[t]{2}{*}{ Slovenia } & Female & Mean & 2.23 & 2.68 & 2.45 & 3.57 & 2.40 \\
\hline & Male & Mean & 2.39 & 2.64 & 2.60 & 3.20 & 2.01 \\
\hline \multirow[t]{2}{*}{ India } & Female & Mean & 1.80 & 2.80 & 2.00 & 3.80 & 2.20 \\
\hline & Male & Mean & 1.91 & 2.18 & 2.00 & 3.36 & 1.91 \\
\hline \multirow[t]{2}{*}{ Rest of the world } & Female & Mean & 2.13 & 3.25 & 1.88 & 4.13 & 3.13 \\
\hline & Male & Mean & 2.13 & 3.75 & 2.13 & 3.63 & 2.00 \\
\hline \multirow[t]{4}{*}{ Total } & Female & Mean & 2.16 & 3.09 & 2.14 & 3.76 & 2.76 \\
\hline & Female & Std. dev. & 1.102 & 1.101 & 1.111 & 1.291 & 1.247 \\
\hline & Male & Mean & 2.27 & 2.84 & 2.22 & 3.48 & 2.37 \\
\hline & Male & Std. dev. & 1.105 & 1.543 & 1.113 & 1.257 & 1.208 \\
\hline
\end{tabular}

question $3\left(D 3 P_{v}=0.000\right)$ regarding work-related stress as an entrepreneur, and desirability question $4\left(D 4 P_{v}=0.000\right)$ regarding enthusiasm about entrepreneurial initiatives.

\section{Countrywise differences with respect to feasibility}

Based on the significance values for feasibility questions 1 through 5 , there is a statistically significant difference between countries for the following: desirability question $1\left(F 1 P_{v}=0.000\right)$ regarding level of difficulties associated with entrepreneurial activities, desirability question $2\left(F 2 P_{v}=0.000\right)$ regarding level of certainty associated with success, desirability question $3\left(F 3 P_{v}=0.000\right)$ regarding level of excess work associated with entrepreneurial activities, desirability question 4

Table 5 Summary of ANOVA results

\begin{tabular}{llll}
\hline & Among different countries & Among different genders & $\begin{array}{l}\text { Among different genders in } \\
\text { different countries }\end{array}$ \\
\hline Differences in desirability & $\begin{array}{l}\text { Significant differences } \\
\text { were found in all cases }\end{array}$ & $\begin{array}{l}\text { Significant differences were } \\
\text { found in all but one case }\end{array}$ & $\begin{array}{l}\text { Significant differences were } \\
\text { found depending on the } \\
\text { country }\end{array}$ \\
Differences in feasibility & $\begin{array}{l}\text { Significant differences } \\
\text { were found in all cases }\end{array}$ & $\begin{array}{l}\text { Significant differences were } \\
\text { found in all cases }\end{array}$ & $\begin{array}{l}\text { Significant differences were } \\
\text { found depending on the } \\
\text { country }\end{array}$ \\
\hline
\end{tabular}


Table 6 Desirability and feasibility differences between countries-ANOVA

\begin{tabular}{|c|c|c|c|c|c|c|}
\hline & & Sum of squares & $\mathrm{df}$ & Mean square & $F$ & Sig. \\
\hline \multirow[t]{3}{*}{ Desirability 1} & Between groups & 2775.778 & 8 & 346.972 & 159.710 & .000 \\
\hline & Within groups & 9144.115 & 4209 & 2.173 & & \\
\hline & Total & $11,919.894$ & 4217 & & & \\
\hline \multirow[t]{3}{*}{ Desirability 2} & Between groups & 3289.738 & 8 & 411.217 & 146.154 & .000 \\
\hline & Within groups & $11,833.948$ & 4206 & 2.814 & & \\
\hline & Total & $15,123.685$ & 4214 & & & \\
\hline \multirow[t]{3}{*}{ Desirability 3} & Between groups & 1444.878 & 8 & 180.610 & 98.994 & .000 \\
\hline & Within groups & 7673.663 & 4206 & 1.824 & & \\
\hline & Total & 9118.541 & 4214 & & & \\
\hline \multirow[t]{3}{*}{ Desirability 4} & Between groups & 2922.443 & 8 & 365.305 & 240.145 & .000 \\
\hline & Within groups & 6396.598 & 4205 & 1.521 & & \\
\hline & Total & 9319.041 & 4213 & & & \\
\hline \multirow[t]{3}{*}{ Feasibility 1} & Between groups & 379.611 & 8 & 47.451 & 41.907 & .000 \\
\hline & Within groups & 4776.065 & 4218 & 1.132 & & \\
\hline & Total & 5155.675 & 4226 & & & \\
\hline \multirow[t]{3}{*}{ Feasibility 2} & Between groups & 338.531 & 8 & 42.316 & 26.864 & .000 \\
\hline & Within groups & 6639.460 & 4215 & 1.575 & & \\
\hline & Total & 6977.991 & 4223 & & & \\
\hline \multirow[t]{3}{*}{ Feasibility 3} & Between groups & 538.126 & 8 & 67.266 & 60.560 & .000 \\
\hline & Within groups & 4681.749 & 4215 & 1.111 & & \\
\hline & Total & 5219.875 & 4223 & & & \\
\hline \multirow[t]{3}{*}{ Feasibility 4} & Between groups & 327.085 & 8 & 40.886 & 25.896 & .000 \\
\hline & Within groups & 6654.730 & 4215 & 1.579 & & \\
\hline & Total & 6981.814 & 4223 & & & \\
\hline \multirow[t]{3}{*}{ Feasibility 5} & Between groups & 397.251 & 8 & 49.656 & 33.967 & .000 \\
\hline & Within groups & 6177.962 & 4226 & 1.462 & & \\
\hline & Total & 6575.213 & 4234 & & & \\
\hline
\end{tabular}

$\left(F 4 P_{v}=0.000\right)$ regarding level of knowledge required for entrepreneurial activities, and desirability question $5\left(F 5 P_{v}=0.000\right)$ regarding level of self-esteem.

From Table 7, at the $5 \%$ level of significance, ANOVA results for genderwise differences with respect to perceived desirability- and perceived feasibility-related variables can be seen.

\section{Genderwise differences with respect to desirability}

Based on the significance values for desirability questions 1 through 4 in Table 7, there is a statistically significant difference between genders for the following: desirability question $1\left(D 1 P_{v}=0.000\right)$ regarding attitudes towards entrepreneurial initiatives, desirability question $3\left(D 3 P_{v}=0.001\right)$ regarding work-related stress as an entrepreneur, and desirability question $4\left(D 4 P_{v}=0.000\right)$ regarding enthusiasm about entrepreneurial initiatives whereas there is no statistically significant 
Table 7 Desirability and feasibility differences between genders-ANOVA

\begin{tabular}{|c|c|c|c|c|c|c|}
\hline & & Sum of squares & $\mathrm{df}$ & Mean square & $F$ & Sig. \\
\hline \multirow[t]{3}{*}{ Feasibility 1} & Between groups & 13.774 & 1 & 13.774 & 11.314 & .001 \\
\hline & Within groups & 5139.783 & 4222 & 1.217 & & \\
\hline & Total & 5153.557 & 4223 & & & \\
\hline \multirow[t]{3}{*}{ Feasibility 2} & Between groups & 58.238 & 1 & 58.238 & 35.508 & .000 \\
\hline & Within groups & 6919.753 & 4219 & 1.640 & & \\
\hline & Total & 6977.991 & 4220 & & & \\
\hline \multirow[t]{3}{*}{ Feasibility 3} & Between groups & 6.668 & 1 & 6.668 & 5.397 & .020 \\
\hline & Within groups & 5211.806 & 4219 & 1.235 & & \\
\hline & Total & 5218.474 & 4220 & & & \\
\hline \multirow[t]{3}{*}{ Feasibility 4} & Between groups & 80.262 & 1 & 80.262 & 49.082 & .000 \\
\hline & Within groups & 6899.205 & 4219 & 1.635 & & \\
\hline & Total & 6979.467 & 4220 & & & \\
\hline \multirow[t]{3}{*}{ Feasibility 5} & Between groups & 149.169 & 1 & 149.169 & 98.202 & .000 \\
\hline & Within groups & 6425.371 & 4230 & 1.519 & & \\
\hline & Total & 6574.540 & 4231 & & & \\
\hline \multirow[t]{3}{*}{ Desirability 1} & Between groups & 140.515 & 1 & 140.515 & 50.267 & .000 \\
\hline & Within groups & $11,776.839$ & 4213 & 2.795 & & \\
\hline & Total & $11,917.354$ & 4214 & & & \\
\hline \multirow[t]{3}{*}{ Desirability 2} & Between groups & 2.593 & 1 & 2.593 & 0.722 & .396 \\
\hline & Within groups & $15,118.361$ & 4210 & 3.591 & & \\
\hline & Total & $15,120.953$ & 4211 & & & \\
\hline \multirow[t]{3}{*}{ Desirability 3} & Between groups & 23.155 & 1 & 23.155 & 10.720 & .001 \\
\hline & Within groups & 9093.382 & 4210 & 2.160 & & \\
\hline & Total & 9116.536 & 4211 & & & \\
\hline \multirow[t]{3}{*}{ Desirability 4} & Between groups & 75.164 & 1 & 75.164 & 34.225 & .000 \\
\hline & Within groups & 9243.556 & 4209 & 2.196 & & \\
\hline & Total & 9318.720 & 4210 & & & \\
\hline
\end{tabular}

difference between genders for desirability question $2\left(D 2 P_{v}=0.396\right)$ regarding family support.

\section{Genderwise differences with respect to feasibility}

Based on the significance values for feasibility questions 1 through 5, in Table 7, there is a statistically significant difference between genders for the following: desirability question $1\left(F 1 P_{v}=0.001\right)$ regarding level of difficulties associated with entrepreneurial activities, desirability question $2\left(F 2 P_{v}=0.000\right)$ regarding level of certainty associated with success, desirability question $3\left(F 3 P_{v}=0.000\right)$ regarding level of excess work associated with entrepreneurial activities, desirability question 4 $\left(F 4 P_{v}=0.000\right)$ regarding level of knowledge required for entrepreneurial activities, and desirability question $5\left(F 5 P_{v}=0.000\right)$ regarding level of self-esteem.

ANOVA results for perceived desirability and perceived feasibility differences among different genders in different countries can be seen in the Appendix as Tables (Tables 9 
and 10). ANOVA results show that there are further significant differences between male and female students in different countries in terms of their attitude towards entrepreneurship.

\section{Perceived desirability differences between genders per country}

ANOVA results (Table 9) for genderwise differences per country, with respect to desirability questions 1 through 4 for the $5 \%$ level of significance, exhibit that for desirability question 1 regarding attitudes towards entrepreneurial initiatives there is a statistically significant difference between genders in Croatia $\left(D 1 P_{v}=0.000\right)$, Austria $\left(D 1 P_{v}=0.000\right)$, France $\left(D 1 P_{v}=0.000\right)$, Israel $\left(D 1 P_{v}=0.000\right)$, and India $\left(D 1 P_{v}=0.015\right)$ whereas there is statistically no significant difference between genders in Lithuania $\left(D 1 P_{v}=0.863\right)$, Poland $\left(D 1 P_{v}=0.954\right)$, Slovenia $\left(D 1 P_{v}=0.076\right)$, and the rest of the world $\left(D 1 P_{v}=0.568\right)$.

Based on the significance values for desirability question 2 regarding family support, there is a statistically significant difference between genders in Croatia $\left(D 2 P_{v}=0.001\right)$ whereas there is statistically no significant difference between genders in Austria $\left(D 2 P_{v}\right.$ $=0.894)$, France $\left(D 2 P_{v}=0.974\right)$, Israel $\left(D 2 P_{v}=0.257\right)$, Lithuania $\left(D 2 P_{v}=0.787\right)$, Poland $\left(D 2 P_{v}=0.064\right)$, Slovenia $\left(D 2 P_{v}=0.579\right)$, India $\left(D 2 P_{v}=0.087\right)$, and the rest of the world $\left(D 2 P_{v}=0.855\right)$.

Based on the significance values for desirability question 3 regarding work-related stress as an entrepreneur, there is a statistically significant difference between genders in Croatia $\left(D 3 P_{v}=0.002\right)$, France $\left(D 3 P_{v}=0.015\right)$, and Israel $\left(D 3 P_{v}=0.019\right)$ whereas there is statistically no significant difference between genders in Austria $\left(D 3 P_{v}=0.810\right)$, Lithuania $\left(D 3 P_{v}=0.871\right)$, Poland $\left(D 3 P_{v}=0.448\right)$, Slovenia $\left(D 3 P_{v}=\right.$ $0.957)$, India $\left(D 3 P_{v}=0.589\right)$, and the rest of the world $\left(D 3 P_{v}=0.559\right)$.

Based on the significance values for desirability question 4 regarding enthusiasm about entrepreneurial initiatives, there is a statistically significant difference between genders in Croatia $\left(D 4 P_{v}=0.000\right)$, Austria $\left(D 4 P_{v}=0.000\right)$, France $\left(D 4 P_{v}=0.005\right)$, and India $\left(D 4 P_{v}=0.027\right)$ whereas there is statistically no significant difference between genders in Israel $\left(D 4 P_{v}=0.096\right)$, Lithuania $\left(D 4 P_{v}=\right.$ $0.874)$, Poland $\left(D 4 P_{v}=0.970\right)$, Slovenia $\left(D 4 P_{v}=0.303\right)$, and the rest of the world $\left(D 4 P_{v}=0.723\right)$.

\section{Perceived feasibility differences between genders per country}

ANOVA results (Table 10) for genderwise differences per country, with respect to feasibility questions 1 through 5 for the $5 \%$ level of significance, exhibit that for feasibility question 1 regarding level of difficulties associated with entrepreneurial activities there is a statistically significant difference between genders in Croatia $\left(F 1 P_{v}=0.000\right)$ whereas there is statistically no significant difference between genders in Austria $\left(F 1 P_{v}=0.227\right)$, France $\left(F 1 P_{v}=0.162\right)$, Israel $\left(F 1 P_{v}=0.698\right)$, Lithuania $\left(F 1 P_{v}=0.639\right)$, Poland $\left(F 1 P_{v}=0.102\right)$, Slovenia $\left(F 1 P_{v}=0.179\right)$, India $\left(F 1 P_{v}=0.812\right)$, and the rest of the world $\left(F 1 P_{v}=1.000\right)$.

Based on the significance values for feasibility question 2 regarding the level of certainty associated with success, there is a statistically significant difference between genders in Croatia $\left(F 2 P_{v}=0.001\right)$, Austria $\left(F 2 P_{v}=0.002\right)$, Israel $\left(F 2 P_{v}\right.$ 
$=0.000)$, and Lithuania $\left(F 2 P_{v}=0.001\right)$, whereas there is statistically no significant difference between genders in France $\left(F 2 P_{v}=0.209\right)$, Poland $\left(F 2 P_{v}=0.681\right)$, Slovenia $\left(F 2 P_{v}=0.751\right)$, India $\left(F 2 P_{v}=0.244\right)$, and the rest of the world $\left(F 2 P_{v}=\right.$ $0.483)$.

Based on the significance values for feasibility question 3 regarding the level of excess work associated with entrepreneurial activities, there is a statistically significant difference between genders in Croatia $\left(F 3 P_{v}=0.003\right)$ whereas there is statistically no significant difference between genders in Austria $\left(F 3 P_{v}=0.136\right)$, France $\left(F 3 P_{v}=0.598\right)$, Israel $\left(F 3 P_{v}=0.053\right)$, Lithuania $\left(F 3 P_{v}=0.562\right)$, Poland $\left(F 3 P_{v}=0.198\right)$, Slovenia $\left(F 3 P_{v}=0.220\right)$, India $\left(F 3 P_{v}=0.384\right)$, and the rest of the world $\left(F 3 P_{v}=0.622\right)$.

Based on the significance values for feasibility question 4 regarding the level of knowledge required for entrepreneurial activities, there is a statistically significant difference between genders in Croatia $\left(F 4 P_{v}=0.001\right)$, Austria $\left(F 4 P_{v}=0.000\right)$, France $\left(F 4 P_{v}=0.000\right)$, Lithuania $\left(F 4 P_{v}=0.008\right)$, and Slovenia $\left(F 4 P_{v}=0.012\right)$ whereas there is statistically no significant difference between genders in Israel $\left(F 4 P_{v}=0.080\right)$, Poland $\left(F 4 P_{v}=0.699\right)$, India $\left(F 4 P_{v}=0.384\right)$, and the rest of the world $\left(F 4 P_{v}=0.524\right)$.

Based on the significance values for feasibility question 5 regarding the level of self-esteem, there is a statistically significant difference between genders in Croatia $\left(F 5 P_{v}=0.000\right)$, Austria $\left(F 5 P_{v}=0.000\right)$, France $\left(F 5 P_{v}=0.000\right)$, Israel $\left(F 5 P_{v}=0.001\right)$, Lithuania $\left(F 5 P_{v}=0.001\right)$, Poland $\left(F 5 P_{v}=0.004\right)$, and Slovenia $\left(F 5 P_{v}=0.001\right)$ whereas there is statistically no significant difference between genders in India $\left(F 5 P_{v}=\right.$ $0.639)$ and the rest of the world $\left(F 5 P_{v}=0.060\right)$.

Table 8 is a summary of the gender differences. Those cells with an " $X$ " represent no significant difference between genders. All the other cells indicate significant difference. Croatia seems to be the only country in which females and males exhibit significantly different attitudes regarding all perceived desirability and feasibility aspects.

Based on Table 8, it can be observed that responses to questions D2 (My immediate family members would encourage me to do it), F1 (It would be very hard to do), and F3 (I would be overworked) indicate nearly no significant difference between genders for all cases except Croatia whereas F4 (I know enough to start a

Table 8 Summary of perceived desirability and feasibility differences between genders per country

\begin{tabular}{|c|c|c|c|c|c|c|c|c|c|}
\hline Country & D1 & D2 & D3 & D4 & $\mathrm{F} 1$ & $\mathrm{~F} 2$ & F3 & $\mathrm{F} 4$ & F5 \\
\hline \multicolumn{10}{|l|}{ Croatia } \\
\hline Austria & & $x$ & $x$ & & $x$ & & $x$ & & \\
\hline France & & $x$ & & & $x$ & $x$ & $x$ & & \\
\hline Israel & & $x$ & & $x$ & $x$ & & $x$ & $x$ & \\
\hline Lithuania & $x$ & $x$ & $x$ & $x$ & $x$ & & $x$ & & \\
\hline Poland & $x$ & $x$ & $x$ & $x$ & $x$ & $x$ & $x$ & $x$ & \\
\hline Slovenia & $x$ & $x$ & $x$ & $x$ & $x$ & $x$ & $x$ & & \\
\hline India & & $x$ & $x$ & & $x$ & $x$ & $x$ & $x$ & $x$ \\
\hline Rest of the world & $x$ & $x$ & $x$ & $x$ & $x$ & $x$ & $x$ & $x$ & $x$ \\
\hline
\end{tabular}


business), F5 (I trust myself), and D1 (I would love to do it) indicate quite a bit difference between genders for the majority of the countries included in the study. This might mean that although both genders are aware of the required work and dedication for starting a new business, generally male students are more selfconfident and keen to do it. If Table 8 is analyzed countrywise, then Poland, Slovenia, and India appear not to have considerable amount of difference between male and female genders whereas responses from male and female students from Croatia, Austria, France, and Israel indicate quite strong difference. In the case of India, D1 and D4 are expected to show significant difference in terms of female students scoring higher than males. This result is consistent with the GEM 2002 report where India and Poland are in the top 6 among 29 countries regarding the female share in total entrepreneurial activity. Interestingly, in the same list, Slovenia occupies the 21st position.

\section{Conclusions}

This paper makes significant contributions to the understanding of entrepreneurial perceptions among students. One of the key strengths of this study is that it is based on a wide range of data for students from 10 different countries. Thus, the results are not culturally related but reflect more globally oriented intentions.

This paper explores the factors impacting entrepreneurial behavior in order to identify new educational opportunities for its development. Specifically, there are three major findings. Significant differences were found between genders and countries on their perceptions of desirability and feasibility towards entrepreneurial behavior. This adds to the findings of prior research on gender differences in entrepreneurial attitudes. Moreover, there were differences in how genders differ in different countries which would require further research.

Insights from this study can help educators plan entrepreneurship-oriented programs or courses in a manner that aims to minimize the gender differences in entrepreneurial motivation. Also, policy makers of countries willing to increase the number of female entrepreneurs would benefit from the results regarding which perceptions females show significant differences from males, so they can shape their entrepreneurship-related policies aiming to reduce these differences or alter the perceptions. There were also differences in how countries differ in terms of perceived feasibility and desirability. These differences can result from social security policies, economic activity, regulatory issues, or sectoral concentration of recent entrepreneurial activities, etc. specific to each country, which can affect the intention of starting a new business negatively. Further research revealing that differences' direction would also help policy makers to understand their countries' potential entrepreneurs' perceptions about those aspects and to alter them.

One shortcoming of this study might be the varying sample sizes from different countries. Sample sizes vary from 1918 to 16, and they are not determined relatively to the student population in those countries. More balanced sample size from examined countries would lead to more meaningful results. For further research also, the effect of students' training areas (engineering, business, social sciences, etc.) on their entrepreneurial perceptions can be examined. 


\section{Appendix}

Table 9 Desirability differences between genders per country-ANOVA

\begin{tabular}{|c|c|c|c|c|c|c|c|}
\hline \multicolumn{8}{|l|}{ ANOVA } \\
\hline Country & & & Sum of squares & $\mathrm{df}$ & Mean square & $F$ & Sig. \\
\hline \multirow[t]{12}{*}{ Croatia } & Desirability 1 & Between groups & 29.840 & 1 & 29.840 & 13.322 & .000 \\
\hline & & Within groups & 4291.598 & 1916 & 2.240 & & \\
\hline & & Total & 4321.437 & 1917 & & & \\
\hline & Desirability 2 & Between groups & 17.688 & 1 & 17.688 & 11.284 & .001 \\
\hline & & Within groups & 3003.501 & 1916 & 1.568 & & \\
\hline & & Total & 3021.189 & 1917 & & & \\
\hline & Desirability 3 & Between groups & 15.785 & 1 & 15.785 & 9.263 & .002 \\
\hline & & Within groups & 3265.144 & 1916 & 1.704 & & \\
\hline & & Total & 3280.929 & 1917 & & & \\
\hline & Desirability 4 & Between groups & 26.133 & 1 & 26.133 & 18.588 & .000 \\
\hline & & Within groups & 2693.657 & 1916 & 1.406 & & \\
\hline & & Total & 2719.790 & 1917 & & & \\
\hline \multirow[t]{12}{*}{ Austria } & Desirability 1 & Between groups & 36.911 & 1 & 36.911 & 14.370 & .000 \\
\hline & & Within groups & 1384.538 & 539 & 2.569 & & \\
\hline & & Total & 1421.449 & 540 & & & \\
\hline & Desirability 2 & Between groups & 0.046 & 1 & 0.046 & 0.018 & .894 \\
\hline & & Within groups & 1392.398 & 539 & 2.583 & & \\
\hline & & Total & 1392.444 & 540 & & & \\
\hline & Desirability 3 & Between groups & 0.085 & 1 & 0.085 & 0.058 & .810 \\
\hline & & Within groups & 786.721 & 539 & 1.460 & & \\
\hline & & Total & 786.806 & 540 & & & \\
\hline & Desirability 4 & Between groups & 32.178 & 1 & 32.178 & 16.737 & .000 \\
\hline & & Within groups & 1036.255 & 539 & 1.923 & & \\
\hline & & Total & 1068.433 & 540 & & & \\
\hline \multirow[t]{12}{*}{ France } & Desirability 1 & Between groups & 30.707 & 1 & 30.707 & 12.411 & .000 \\
\hline & & Within groups & 1088.643 & 440 & 2.474 & & \\
\hline & & Total & 1119.351 & 441 & & & \\
\hline & Desirability 2 & Between groups & 0.002 & 1 & 0.002 & 0.001 & .974 \\
\hline & & Within groups & 946.848 & 440 & 2.152 & & \\
\hline & & Total & 946.851 & 441 & & & \\
\hline & Desirability 3 & Between groups & 11.560 & 1 & 11.560 & 5.979 & .015 \\
\hline & & Within groups & 850.669 & 440 & 1.933 & & \\
\hline & & Total & 862.229 & 441 & & & \\
\hline & Desirability 4 & Between groups & 14.302 & 1 & 14.302 & 7.905 & .005 \\
\hline & & Within groups & 796.080 & 440 & 1.809 & & \\
\hline & & Total & 810.382 & 441 & & & \\
\hline \multirow[t]{6}{*}{ Israel } & Desirability 1 & Between groups & 54.667 & 1 & 54.667 & 22.442 & .000 \\
\hline & & Within groups & 643.092 & 264 & 2.436 & & \\
\hline & & Total & 697.759 & 265 & & & \\
\hline & Desirability 2 & Between groups & 20.394 & 1 & 20.394 & 1.292 & .257 \\
\hline & & Within groups & 4151.847 & 263 & 15.786 & & \\
\hline & & Total & 4172.242 & 264 & & & \\
\hline
\end{tabular}


Table 9 Desirability differences between genders per country-ANOVA (Continued)

\begin{tabular}{|c|c|c|c|c|c|c|c|}
\hline & Desirability 3 & Between groups & 8.673 & 1 & 8.673 & 5.589 & .019 \\
\hline & & Within groups & 411.245 & 265 & 1.552 & & \\
\hline & & Total & 419.918 & 266 & & & \\
\hline & Desirability 4 & Between groups & 4.859 & 1 & 4.859 & 2.795 & .096 \\
\hline & & Within groups & 458.979 & 264 & 1.739 & & \\
\hline & & Total & 463.838 & 265 & & & \\
\hline \multirow[t]{12}{*}{ Lithuania } & Desirability 1 & Between groups & 0.027 & 1 & 0.027 & 0.030 & .863 \\
\hline & & Within groups & 358.950 & 394 & 0.911 & & \\
\hline & & Total & 358.977 & 395 & & & \\
\hline & Desirability 2 & Between groups & 0.075 & 1 & 0.075 & 0.073 & .787 \\
\hline & & Within groups & 402.497 & 393 & 1.024 & & \\
\hline & & Total & 402.572 & 394 & & & \\
\hline & Desirability 3 & Between groups & 0.021 & 1 & 0.021 & 0.026 & .871 \\
\hline & & Within groups & 321.751 & 393 & 0.819 & & \\
\hline & & Total & 321.772 & 394 & & & \\
\hline & Desirability 4 & Between groups & 0.020 & 1 & 0.020 & 0.025 & .874 \\
\hline & & Within groups & 306.425 & 394 & 0.778 & & \\
\hline & & Total & 306.444 & 395 & & & \\
\hline \multirow[t]{12}{*}{ Poland } & Desirability 1 & Between groups & 0.004 & 1 & 0.004 & 0.003 & .954 \\
\hline & & Within groups & 406.531 & 312 & 1.303 & & \\
\hline & & Total & 406.535 & 313 & & & \\
\hline & Desirability 2 & Between groups & 14.849 & 1 & 14.849 & 3.452 & .064 \\
\hline & & Within groups & 1337.777 & 311 & 4.302 & & \\
\hline & & Total & 1352.626 & 312 & & & \\
\hline & Desirability 3 & Between groups & 2.832 & 1 & 2.832 & 0.576 & .448 \\
\hline & & Within groups & 1518.898 & 309 & 4.916 & & \\
\hline & & Total & 1521.730 & 310 & & & \\
\hline & Desirability 4 & Between groups & 0.002 & 1 & 0.002 & 0.001 & .970 \\
\hline & & Within groups & 394.269 & 308 & 1.280 & & \\
\hline & & Total & 394.271 & 309 & & & \\
\hline \multirow[t]{12}{*}{ Slovenia } & Desirability 1 & Between groups & 7.720 & 1 & 7.720 & 3.177 & .076 \\
\hline & & Within groups & 738.806 & 304 & 2.430 & & \\
\hline & & Total & 746.526 & 305 & & & \\
\hline & Desirability 2 & Between groups & 0.488 & 1 & 0.488 & 0.308 & .579 \\
\hline & & Within groups & 481.185 & 304 & 1.583 & & \\
\hline & & Total & 481.673 & 305 & & & \\
\hline & Desirability 3 & Between groups & 0.004 & 1 & 0.004 & 0.003 & .957 \\
\hline & & Within groups & 421.748 & 304 & 1.387 & & \\
\hline & & Total & 421.752 & 305 & & & \\
\hline & Desirability 4 & Between groups & 2.017 & 1 & 2.017 & 1.064 & .303 \\
\hline & & Within groups & 576.470 & 304 & 1.896 & & \\
\hline & & Total & 578.487 & 305 & & & \\
\hline \multirow[t]{3}{*}{ India } & Desirability 1 & Between groups & 9.828 & 1 & 9.828 & 7.598 & .015 \\
\hline & & Within groups & 18.109 & 14 & 1.294 & & \\
\hline & & Total & 27.937 & 15 & & & \\
\hline
\end{tabular}


Table 9 Desirability differences between genders per country-ANOVA (Continued)

\begin{tabular}{|c|c|c|c|c|c|c|c|}
\hline & \multirow[t]{3}{*}{ Desirability 2} & Between groups & 7.092 & 1 & 7.092 & \multirow[t]{3}{*}{3.383} & \multirow[t]{3}{*}{.087} \\
\hline & & Within groups & 29.345 & 14 & 2.096 & & \\
\hline & & Total & 36.437 & 15 & & & \\
\hline & \multirow[t]{3}{*}{ Desirability 3} & Between groups & 1.023 & 1 & 1.023 & \multirow[t]{3}{*}{0.306} & \multirow[t]{3}{*}{.589} \\
\hline & & Within groups & 46.727 & 14 & 3.338 & & \\
\hline & & Total & 47.750 & 15 & & & \\
\hline & \multirow[t]{3}{*}{ Desirability 4} & Between groups & 8.210 & 1 & 8.210 & \multirow[t]{3}{*}{6.138} & \multirow[t]{3}{*}{.027} \\
\hline & & Within groups & 18.727 & 14 & 1.338 & & \\
\hline & & Total & 26.938 & 15 & & & \\
\hline \multirow[t]{12}{*}{ Rest of the world } & \multirow[t]{3}{*}{ Desirability 1} & Between groups & 1.000 & 1 & 1.000 & \multirow[t]{3}{*}{0.341} & \multirow[t]{3}{*}{.568} \\
\hline & & Within groups & 41.000 & 14 & 2.929 & & \\
\hline & & Total & 42.000 & 15 & & & \\
\hline & \multirow[t]{3}{*}{ Desirability 2} & Between groups & 0.062 & 1 & 0.062 & \multirow[t]{3}{*}{0.034} & \multirow[t]{3}{*}{.855} \\
\hline & & Within groups & 25.375 & 14 & 1.812 & & \\
\hline & & Total & 25.438 & 15 & & & \\
\hline & \multirow[t]{3}{*}{ Desirability 3} & Between groups & 0.250 & 1 & 0.250 & \multirow[t]{3}{*}{0.359} & \multirow[t]{3}{*}{.559} \\
\hline & & Within groups & 9.750 & 14 & 0.696 & & \\
\hline & & Total & 10.000 & 15 & & & \\
\hline & \multirow[t]{3}{*}{ Desirability 4} & Between groups & 0.250 & 1 & 0.250 & \multirow[t]{3}{*}{0.131} & \multirow[t]{3}{*}{.723} \\
\hline & & Within groups & 26.750 & 14 & 1.911 & & \\
\hline & & Total & 27.000 & 15 & & & \\
\hline
\end{tabular}


Table 10 Feasibility differences between genders per country-ANOVA

\begin{tabular}{|c|c|c|c|c|c|c|c|}
\hline \multicolumn{8}{|l|}{ ANOVA } \\
\hline Country & & & Sum of squares & $\mathrm{df}$ & Mean square & $F$ & Sig. \\
\hline \multirow[t]{15}{*}{ Croatia } & Feasibility 1 & Between groups & 15.230 & 1 & 15.230 & 14.211 & .000 \\
\hline & & Within groups & 2053.466 & 1916 & 1.072 & & \\
\hline & & Total & 2068.697 & 1917 & & & \\
\hline & Feasibility 2 & Between groups & 11.942 & 1 & 11.942 & 10.714 & .001 \\
\hline & & Within groups & 2135.786 & 1916 & 1.115 & & \\
\hline & & Total & 2147.729 & 1917 & & & \\
\hline & Feasibility 3 & Between groups & 8.513 & 1 & 8.513 & 8.708 & .003 \\
\hline & & Within groups & 1873.149 & 1916 & 0.978 & & \\
\hline & & Total & 1881.662 & 1917 & & & \\
\hline & Feasibility 4 & Between groups & 16.340 & 1 & 16.340 & 11.625 & .001 \\
\hline & & Within groups & 2693.071 & 1916 & 1.406 & & \\
\hline & & Total & 2709.412 & 1917 & & & \\
\hline & Feasibility 5 & Between groups & 31.051 & 1 & 31.051 & 22.386 & .000 \\
\hline & & Within groups & 2657.637 & 1916 & 1.387 & & \\
\hline & & Total & 2688.689 & 1917 & & & \\
\hline \multirow[t]{15}{*}{ Austria } & Feasibility 1 & Between groups & 1.741 & 1 & 1.741 & 1.463 & .227 \\
\hline & & Within groups & 641.408 & 539 & 1.190 & & \\
\hline & & Total & 643.150 & 540 & & & \\
\hline & Feasibility 2 & Between groups & 14.370 & 1 & 14.370 & 9.240 & .002 \\
\hline & & Within groups & 838.281 & 539 & 1.555 & & \\
\hline & & Total & 852.651 & 540 & & & \\
\hline & Feasibility 3 & Between groups & 2.421 & 1 & 2.421 & 2.235 & .136 \\
\hline & & Within groups & 584.000 & 539 & 1.083 & & \\
\hline & & Total & 586.421 & 540 & & & \\
\hline & Feasibility 4 & Between groups & 42.879 & 1 & 42.879 & 17.309 & .000 \\
\hline & & Within groups & 1335.276 & 539 & 2.477 & & \\
\hline & & Total & 1378.155 & 540 & & & \\
\hline & Feasibility 5 & Between groups & 27.350 & 1 & 27.350 & 18.554 & .000 \\
\hline & & Within groups & 794.509 & 539 & 1.474 & & \\
\hline & & Total & 821.860 & 540 & & & \\
\hline \multirow[t]{12}{*}{ France } & Feasibility 1 & Between groups & 1.748 & 1 & 1.748 & 1.963 & .162 \\
\hline & & Within groups & 391.809 & 440 & 0.890 & & \\
\hline & & Total & 393.557 & 441 & & & \\
\hline & Feasibility 2 & Between groups & 1.859 & 1 & 1.859 & 1.585 & .209 \\
\hline & & Within groups & 516.315 & 440 & 1.173 & & \\
\hline & & Total & 518.174 & 441 & & & \\
\hline & Feasibility 3 & Between groups & 0.358 & 1 & 0.358 & 0.278 & .598 \\
\hline & & Within groups & 565.663 & 440 & 1.286 & & \\
\hline & & Total & 566.020 & 441 & & & \\
\hline & Feasibility 4 & Between groups & 22.219 & 1 & 22.219 & 12.823 & .000 \\
\hline & & Within groups & 762.426 & 440 & 1.733 & & \\
\hline & & Total & 784.645 & 441 & & & \\
\hline
\end{tabular}


Table 10 Feasibility differences between genders per country-ANOVA (Continued)

\begin{tabular}{|c|c|c|c|c|c|c|c|}
\hline & Feasibility 5 & Between groups & 39.155 & 1 & 39.155 & 19.977 & .000 \\
\hline & & Within groups & 862.401 & 440 & 1.960 & & \\
\hline & & Total & 901.557 & 441 & & & \\
\hline \multirow[t]{15}{*}{ Israel } & Feasibility 1 & Between groups & 0.124 & 1 & 0.124 & 0.151 & .698 \\
\hline & & Within groups & 222.016 & 271 & 0.819 & & \\
\hline & & Total & 222.139 & 272 & & & \\
\hline & Feasibility 2 & Between groups & 10.525 & 1 & 10.525 & 14.152 & .000 \\
\hline & & Within groups & 200.795 & 270 & 0.744 & & \\
\hline & & Total & 211.320 & 271 & & & \\
\hline & Feasibility 3 & Between groups & 3.361 & 1 & 3.361 & 3.780 & .053 \\
\hline & & Within groups & 239.178 & 269 & 0.889 & & \\
\hline & & Total & 242.539 & 270 & & & \\
\hline & Feasibility 4 & Between groups & 3.061 & 1 & 3.061 & 3.095 & .080 \\
\hline & & Within groups & 266.994 & 270 & 0.989 & & \\
\hline & & Total & 270.055 & 271 & & & \\
\hline & Feasibility 5 & Between groups & 11.414 & 1 & 11.414 & 10.930 & .001 \\
\hline & & Within groups & 282.982 & 271 & 1.044 & & \\
\hline & & Total & 294.396 & 272 & & & \\
\hline \multirow[t]{15}{*}{ Lithuania } & Feasibility 1 & Between groups & 0.476 & 1 & 0.476 & 0.220 & .639 \\
\hline & & Within groups & 857.484 & 397 & 2.160 & & \\
\hline & & Total & 857.960 & 398 & & & \\
\hline & Feasibility 2 & Between groups & 19.815 & 1 & 19.815 & 10.473 & .001 \\
\hline & & Within groups & 751.087 & 397 & 1.892 & & \\
\hline & & Total & 770.902 & 398 & & & \\
\hline & Feasibility 3 & Between groups & 0.672 & 1 & 0.672 & 0.337 & .562 \\
\hline & & Within groups & 791.168 & 397 & 1.993 & & \\
\hline & & Total & 791.840 & 398 & & & \\
\hline & Feasibility 4 & Between groups & 12.899 & 1 & 12.899 & 7.141 & .008 \\
\hline & & Within groups & 717.091 & 397 & 1.806 & & \\
\hline & & Total & 729.990 & 398 & & & \\
\hline & Feasibility 5 & Between groups & 21.679 & 1 & 21.679 & 10.985 & .001 \\
\hline & & Within groups & 783.494 & 397 & 1.974 & & \\
\hline & & Total & 805.173 & 398 & & & \\
\hline \multirow[t]{12}{*}{ Poland } & Feasibility 1 & Between groups & 2.398 & 1 & 2.398 & 2.693 & .102 \\
\hline & & Within groups & 276.874 & 311 & 0.890 & & \\
\hline & & Total & 279.272 & 312 & & & \\
\hline & Feasibility 2 & Between groups & 0.972 & 1 & 0.972 & 0.169 & .681 \\
\hline & & Within groups & 1777.523 & 309 & 5.753 & & \\
\hline & & Total & 1778.495 & 310 & & & \\
\hline & Feasibility 3 & Between groups & 1.547 & 1 & 1.547 & 1.662 & .198 \\
\hline & & Within groups & 288.441 & 310 & 0.930 & & \\
\hline & & Total & 289.987 & 311 & & & \\
\hline & Feasibility 4 & Between groups & 0.137 & 1 & 0.137 & 0.150 & 699 \\
\hline & & Within groups & 282.358 & 309 & 0.914 & & \\
\hline & & Total & 282.495 & 310 & & & \\
\hline
\end{tabular}


Table 10 Feasibility differences between genders per country-ANOVA (Continued)

\begin{tabular}{|c|c|c|c|c|c|c|c|}
\hline & Feasibility 5 & Between groups & 8.307 & 1 & 8.307 & 8.188 & .004 \\
\hline & & Within groups & 324.665 & 320 & 1.015 & & \\
\hline & & Total & 332.972 & 321 & & & \\
\hline \multirow{15}{*}{ Slovenia } & Feasibility 1 & Between groups & 1.659 & 1 & 1.659 & 1.810 & .179 \\
\hline & & Within groups & 278.606 & 304 & 0.916 & & \\
\hline & & Total & 280.265 & 305 & & & \\
\hline & Feasibility 2 & Between groups & 0.106 & 1 & 0.106 & 0.101 & .751 \\
\hline & & Within groups & 317.894 & 304 & 1.046 & & \\
\hline & & Total & 318.000 & 305 & & & \\
\hline & Feasibility 3 & Between groups & 1.485 & 1 & 1.485 & 1.510 & .220 \\
\hline & & Within groups & 299.015 & 304 & 0.984 & & \\
\hline & & Total & 300.500 & 305 & & & \\
\hline & Feasibility 4 & Between groups & 9.357 & 1 & 9.357 & 6.430 & .012 \\
\hline & & Within groups & 442.408 & 304 & 1.455 & & \\
\hline & & Total & 451.765 & 305 & & & \\
\hline & Feasibility 5 & Between groups & 10.480 & 1 & 10.480 & 11.246 & .001 \\
\hline & & Within groups & 282.385 & 303 & 0.932 & & \\
\hline & & Total & 292.866 & 304 & & & \\
\hline \multirow[t]{15}{*}{ India } & Feasibility 1 & Between groups & 0.041 & 1 & 0.041 & 0.059 & .812 \\
\hline & & Within groups & 9.709 & 14 & 0.694 & & \\
\hline & & Total & 9.750 & 15 & & & \\
\hline & Feasibility 2 & Between groups & 1.314 & 1 & 1.314 & 1.479 & .244 \\
\hline & & Within groups & 12.436 & 14 & 0.888 & & \\
\hline & & Total & 13.750 & 15 & & & \\
\hline & Feasibility 3 & Between groups & 0.000 & 1 & 0.000 & 0.000 & 1.000 \\
\hline & & Within groups & 8.000 & 14 & 0.571 & & \\
\hline & & Total & 8.000 & 15 & & & \\
\hline & Feasibility 4 & Between groups & 0.655 & 1 & 0.655 & 0.808 & .384 \\
\hline & & Within groups & 11.345 & 14 & 0.810 & & \\
\hline & & Total & 12.000 & 15 & & & \\
\hline & Feasibility 5 & Between groups & 0.291 & 1 & 0.291 & 0.230 & .639 \\
\hline & & Within groups & 17.709 & 14 & 1.265 & & \\
\hline & & Total & 18.000 & 15 & & & \\
\hline \multirow[t]{12}{*}{ Rest of the world } & Feasibility 1 & Between groups & 0.000 & 1 & 0.000 & 0.000 & 1.000 \\
\hline & & Within groups & 19.750 & 14 & 1.411 & & \\
\hline & & Total & 19.750 & 15 & & & \\
\hline & Feasibility 2 & Between groups & 1.000 & 1 & 1.000 & 0.519 & .483 \\
\hline & & Within groups & 27.000 & 14 & 1.929 & & \\
\hline & & Total & 28.000 & 15 & & & \\
\hline & Feasibility 3 & Between groups & 0.250 & 1 & 0.250 & 0.255 & .622 \\
\hline & & Within groups & 13.750 & 14 & 0.982 & & \\
\hline & & Total & 14.000 & 15 & & & \\
\hline & Feasibility 4 & Between groups & 1.000 & 1 & 1.000 & 0.427 & .524 \\
\hline & & Within groups & 32.750 & 14 & 2.339 & & \\
\hline & & Total & 33.750 & 15 & & & \\
\hline
\end{tabular}


Table 10 Feasibility differences between genders per country-ANOVA (Continued)

\begin{tabular}{lllllll}
\hline Feasibility 5 & Between groups & 5.062 & 1 & 5.062 & 4.200 & .060 \\
& Within groups & 16.875 & 14 & 1.205 & & \\
& Total & 21.938 & 15 & & & \\
\hline
\end{tabular}

\section{Competing interests}

The authors declare that they have no competing interests

\section{Authors' contributions}

All authors contributed to this project equally from inception to the end. All authors read and approved the final manuscript.

\section{Acknowledgements}

The results of this paper are supported by the EU Commission grant Tempus 144713 Fostering Entrepreneurship in Higher Education, FoSentHE.

\section{Author details}

${ }^{1}$ Technology Management Doctoral Program, Portland State University, 1900 SW 4th, Portland, OR 97201, USA. ${ }^{2}$ Faculty of Economics and Business, University of Zagreb, Zagreb, Croatia. ${ }^{3}$ Nottingham Business School, Nottingham Trent University, Nottingham, UK. ${ }^{4}$ Department of Industrial Engineering, Istanbul Technical University, Macka, Istanbul, Turkey.

Received: 29 October 2015 Accepted: 20 April 2016

\section{Published online: 17 May 2016}

\section{References}

Ajzen, I. (1991). The theory of planned behavior. Organizational Behavior and Human Decision Processes, 50(2), 179-211. Blanchflower, D. G., Oswald, A., \& Stutzer, A. (2001). Latent entrepreneurship across nations. European Economic Review, 45, 680-691.

Carayannis, E. G., Evans, D., \& Hanson, M. (2003). A cross-cultural learning strategy for entrepreneurship education: outline of key concepts and lessons learned from a comparative study of entrepreneurship students in France and the US. Technovation, 23(9), 757-771.

Chell, E., \& Allman, K. (2003). Mapping the motivations and intentions of technology oriented entrepreneurs. R\&D Management, 33(2), 117-134.

Dabić, M.et.al. (2012a) Exploring gender differences in attitudes of university students towards entrepreneurship: an international survey International Journal of Gender and Entrepreneurship, 4(3), pp. 316-336.

Dabić, Marina; Bašić, Maja; Novak, Ivan; Daim, Tugrul;Bayraktaroglu, Elvan. (2012b). Study of entrepreneurial environment based on cross country differences. Southern Journal of Entrepreneurship. 4(2); 68-86

Eddleston, K. A., \& Powell, G. N. (2008). The role of gender identity in explaining sex differences in business owners' career satisfier preferences. Journal of Business Venturing, 23, 244-256.

Elenurm, T., Ennulo, J., \& Laar, J. (2007). Structures of motivation and entrepreneurial orientation in students as the basis for differentiated approaches in developing human resources for future business initiatives. EBS Review, 23(2), 50-61.

Fischer, E. M., Reuber, A. R., \& Dyke, L. S. (1993). A theoretical overview and extension of research on sex, gender, and entrepreneurship. Journal of Business Venturing, 8(2), 151-168.

Freytag, A., \& Thurik, R. (2007). Entrepreneurship and its determinants in a cross-country setting. Journal of Evolutionary Economics, 17, 117-131.

Gerry, C., \& Marques, C. S. (2008). Tracking student entrepreneurial potential: personal attributes and the propensity for business start-ups after graduation in a Portuguese university. Problems and Perspectives in Management, 6(4), 46-54

Grilo, I., Irigoyen, J.M. (2005) Entrepreneurship in the EU: to wish and not to be. Discussion Papers on Entrepreneurship, Growth and Public Policy, MPI Jena.

Grilo, I., \& Thurik, R. (2005). Latent and actual entrepreneurship in Europe and the US: some recent developments. International Entrepreneurship and Management Journal, 1, 441-459.

Hines, G. (1973). Achievement motivation, occupations and labour turnover on New Zealand. Journal of Applied Psychology, 58(3), 313-317.

Huffman, D., \& Quigley, J. M. (2002). The role of the university in attracting high tech entrepreneurship: a Silicon Valley tale. The Annals of Regional Science, 36, 403-429.

Johnson, D., Craig, J. B. L., \& Hildebrand, R. (2006). Entrepreneurship education: towards a discipline based framework Journal of Management Development, 25(1), 40-54.

Keilbach, M., Sanders, M. (2008). The contribution of entrepreneurship to economic growth. In: M. Keilbach et al. (eds). Sustaining entrepreneurship and economic growth-lessons in policy and industry innovations from Germany and India. (pp. 7-25). New York: Springer Science + Business Media.

Kelley, D., Bosma, N., Amoros, J.E. (2010). Global entrepreneurship monitor 2010 global report. Babson College, Universidad del Desarrollo and London Business School.

Kourilsky, M. L., \& Walstad, W. B. (1998). Entrepreneurship and female youth: knowledge, attitudes, gender differences, and educational practices. Journal of Business Venturing, 13(1), 77-88. 
Krueger, N., \& Brazeal, D. (1994). Entrepreneurial potential and potential entrepreneurs. Entrepreneurship Theory and Practice, $18(1), 5-21$.

Krueger, N., Reilly, M., \& Carsrud, A. (2000). Competing models of entrepreneurial intentions. Journal of Business Venturing, 15(5/6), 411-432.

Lee, S. M., Lim, S., Pathak, R. D., Chang, D., \& Li, W. (2006). Influences on students attitudes toward entrepreneurship: a multi country study. Entrepreneurship Management, 2, 351-366.

Lee, S. H., \& Wong, P. K. (2004). An exploratory study of technopreneurial intentions: a career anchor perspective. Journal of Business Venturing, 19, 7-28.

Liñán, F. (2008). Skill and value perceptions: how do they affect entrepreneurial intentions? International Entrepreneurship Management Journal, 4, 257-272.

Lunati, M., Schlochtern, J.M., Sargsyan, G. (2010) Measuring entrepreneurship—the OECD-Eurostat Entrepreneurship Indicators Programme. France: OECD Statistics Brief, 15.

Luthje, C., \& Franke, N. (2003). The making of an entrepreneur: testing of a model of entrepreneurial intent among engineering students at MIT. R\&D Management, 33(2), 135-147.

Menzies, T., \& Tatroff, H. (2006). The propensity of male vs female students to take courses and degree concentrations in entrepreneurship. Journal of Small Business and Entrepreneurship, 19(2), 203-223.

Petridou, E., Sarri, A., \& Kyrgidou, L. P. (2009). Entrepreneurship education in higher educational institutions: the gender dimension. Gender in Management: An International Journal, 24(4), 286-309.

Segal, G., Borgia, D., \& Schoenfeld, J. (2005). The motivation to become an entrepreneur. International Journal of Entrepreneurial Behaviour and Research, 11(1), 42-57.

Shapero, A. (1982). Social dimensions of entrepreneurship. In: Summers, D.F. (2000) The formation of entrepreneurial intentions. New York: Garland Publishing Inc.

Shariff, M. N. M., \& Saud, M. B. (2009). An attitude approach to the prediction of entrepreneurship on students at institution of higher learning in Malaysia. Internatioanl Journal of Business and Management, 4(4), 129-135.

Summers, D. F. (2000). The formation of entrepreneurial intentions. New York: Garland Publishing Inc.

Turker, D., \& Selcuk, S. S. (2008). Which factors affect entrepreneurial intentions of university students? Journal of European Industrial Training, 33(2), 142-159.

Veciana, J. M., Aponte, M., \& Urbano, D. (2005). University students' attitudes towards entrepreneurship: a two country comparison. International Entrepreneurship and Management Journal, 1, 165-182.

Verheul, I., van Stel, A., Thurik, R. (2004). Explaining female entrepreneurship across 29 countries. Discussion papers on entrepreneurship, growth and public policy. Max-Planck Institute, pp 1-32.

Wang, C. K., \& Wong, P. (2004). Entrepreneurial interest of university students in Singapore. Technovation, 24, 163-172.

Wu, S., \& Wu, L. (2008). The impact of higher education on entrepreneurial intentions of university students in China. Journal of Small Business and Enterprise Development, 15(4), 752-774.

Zhang, Z., Zyphur, M. J., Narayanan, J., Arvey, R. D., Chaturvedi, S., Avolio, B. J., et al. (2009). The genetic basis of entrepreneurship: effects of gender and personality. Organizational Behavior and Human Decision Processes, 110, 93-107.

Submit your manuscript to a SpringerOpen ${ }^{\odot}$ journal and benefit from:

- Convenient online submission

- Rigorous peer review

- Immediate publication on acceptance

- Open access: articles freely available online

- High visibility within the field

- Retaining the copyright to your article

Submit your next manuscript at $>$ springeropen.com 